GRAD

DT

107.87 .A48 2011
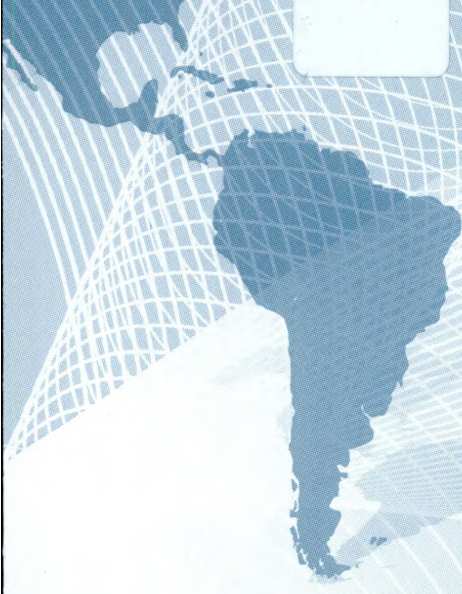

\title{
PRESIDENTIAL SUCCESSION
}

SCENARIOS IN EGYPT AND THEIR

IMPACT ON U.S.-EGYPTIAN STRATEGIC

RELATIONS

Gregory Aftandilian

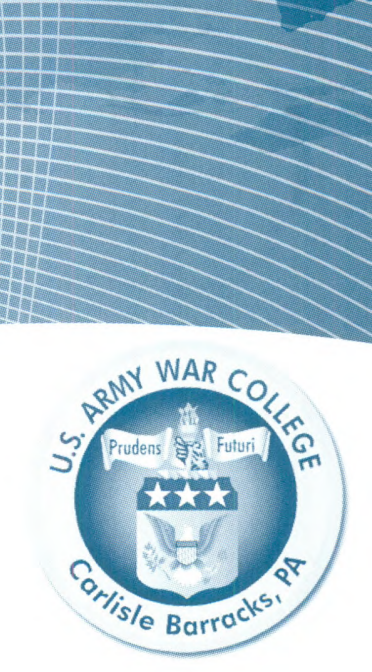

